\title{
経済社会変化による利用ニーズ変動に対応可能 な港湾アセットマネジメント手法の一提案
}

\author{
加藤 博敏 ${ }^{1}$ - 北里 新一郎 ${ }^{2}$ - 兵頭 武志 ${ }^{3}$ - 横田 弘 $^{4}$ \\ ${ }^{1}$ 正会員＼cjkstart前(財)港湾空港建設技術サービスセンター（７ 100-0013 東京都千代田区霞が関 3-3-1 ) \\ E-mail:hirotoshi.katou@cao.go.jp \\ ${ }^{2}$ 正会員 （財)港湾空港建設技術サービスセンター(† 100-0013 東京都千代田区霞が関 3-3-1) \\ E-mail : kitazato@scopenet.or.jp \\ ${ }^{3}$ 正会員 （財)港湾空港建設技術サービスセンター（† 100-0013 東京都千代田区霞が関 3-3-1) \\ E-mail : hyoudou@scopenet.or.jp \\ ${ }^{4}$ フェロー会員 北海道大学大学院 工学研究院 ( $\bar{T} 060-8628$ 札幌市北区北 13 条西 8 丁目) \\ E-mail : yokota@eng.hokudai.ac.jp
}

\begin{abstract}
港湾施設では, 2007 年の関係法令の改正等を受け, 既存施設の点検や維持管理計画書の作成ならびに これに基づく計画的な維持管理が始まっている。しかしながら, 港湾施設は, 国際的な生産拠点の再配置 や定期航路の寄港地選択を始めとした企業の経営判断などにより, 施設利用ニーズが大きく変化するなど の特殊性を有している. アセットマネジメントを行う際には，物理的な劣化現象のみならず，利用者ニー ズの変化というリスクを認識し, その変動に対応したマネジメントが必要となる.

本論文では，まず，港湾施設の維持管理制度と計画的な維持管理のための技術（アセットマネジメント） の現状を示し, 経済社会の変化によって利用ニーズが変動する港湾施設の特殊性とニーズ変動への対応の 必要性について紹介する. その上で, 施設の物理的マネジメントを進める中で, 経済社会の変化にも対応 可能なマネジメント技術の必要性, 構造物の劣化進行状況を総合的に示す指標を用いて行う利用ニーズ変 動対応型のアセットマネジメント手法の提案，ならびにその活用展望について述べる.
\end{abstract}

Key Words : maintenance, asset management, deterioration degree point, user needs

\section{1.港湾の維持管理制度とマネジメント技術の現状}

\section{(1) 港湾施設の維持管理の制度の変遷}

\section{a) 港湾法に基づく港湾施設の維持管理の仕組み}

我が国の港湾施設の代表である係留施設は，国や 港湾管理者が整備する公共岸壁と, 臨海部立地企 業などが自社施設として整備する専用岸壁に大別さ れる. 公共岸壁の内, 国が整備するものは, 一部例 外を除き，港湾法第 54 条に基づき，整備後は港湾 管理者（主に地方自治体）に管理委託することとな っている，港湾管理者は，岸壁係船料などを利用者 から徴収できる一方, 管理費用は自ら負担すること となり，維持管理に関する国の補助金等の直接的な 資金支援はない。 b) 高度成長の陰で潜在化した維持管理の必要性 1951 年に制定された港湾法の体系の下, 戦後の 高度経済成長を追いかけるように急速な港湾施設の 整備が進められた。 やがて, コンテナ船の登場によ る荷役形態の変化や，これに対応する埠頭形状の再 編, 船舶の大型化に伴う岸壁の大型化など, 質の面 からの施設再編が求められるようになった。

大水深岸壁を備えた埠頭が沖側海域に新しく整備 される一方で，古い岸壁を備える埠頭は，機械荷役 に相応しい広いヤード, 市街地の再開発用地, ある いは市民に解放する空間等へと再編が進められた. この結果, 既存岸壁の劣化が顕在化する前（多くは 供用開始後 30 年程度以前 ${ }^{1)}$ ) に，増深や再編のた めの改良が加えられる場合が多く, 本格的な維持管 
理制度が設けられるに至らなかった。

\section{c) 維持管理体制の見直し}

潜在化していた劣化に対する取り組みの必要性 は，経済成長の安定期に移ると顕在化するようにな った．例えば，建設費用を抑制するために供用後の 沈下を許容することとして設計された層厚 $30 \mathrm{~m}$ 規 模の軟弱地盤上の岸壁など, 高度な新技術で整備さ れた施設には，維持管理にも高度な技術力が求めら れることとなった。 また, 維持管理を担う港湾管理 者の財政的負担も看過できない規模となり始めた.

こうした状況の中で，国土交通省交通政策審議会 において「安全で経済的な港湾施設の整備・維持管 理システムのあり方について」の審議が開始された. この答申では, 維持補修計画に基づく港湾施設の適 切な維持管理などの必要性が言及され2)，2007 年に

「港湾の施設の技術上の基準を定める省令」改正と 新たな維持管理告示 ${ }^{3)}$ により, 施設設置者による維 持管理計画の策定や, 維持管理計画に基づく適切な 維持の実施等が, 初めて法令の枠組みの中で明示さ れた。

\section{（2）港湾施設のマネジメントシステムの現状}

省令改正等を受けて刊行された「港湾の施設の維 持管理技術マニュアル」 ${ }^{4)}$ (「マニュアル」という) や「港湾の施設の維持管理計画書作成の手引き(増 補改訂版 $) 」^{5)}$ (「手引き」という）により，港湾施 設の維持管理の基本的枠組みが示された（図-1).

本節では, これらに示された体系の概要と, 関連す る研究の現状を述べる.

\section{a) 施設の点検診断の体系の概要}

技術とデータの蓄積が不十分な中, 膨大な数の施 設を対象に, 専門的知識を要する詳細調査の実施と それら結果に基づく技術的な判断を行うことは現実 には難しい，そのため，「マニュアル」では，施設 の性能低下を定量化するための点検診断において, 部材の外観上の劣化・変状による不具合を, 目視に

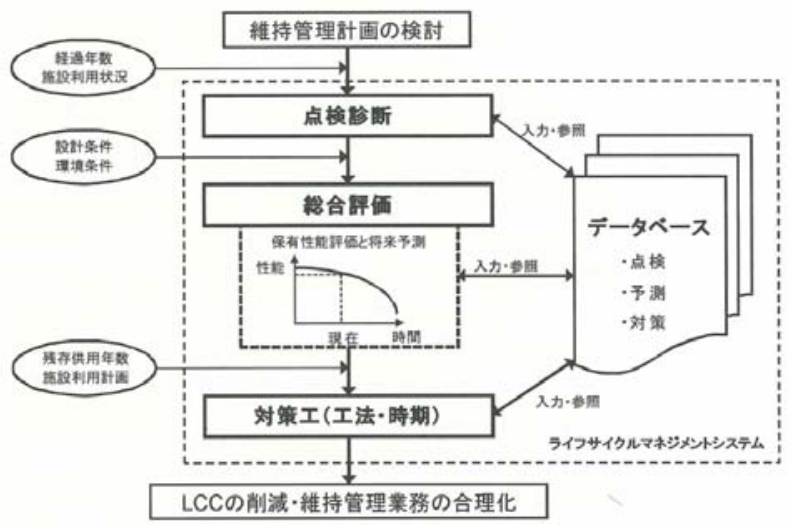

図-1 港湾の施設の維持管理の手順 4)
より $\mathrm{a} \sim \mathrm{d} の 4$ 段階の劣化度として判断し，部材性 能の代替值として用いることとし，部材毎の施設全 体の安全性に及ぼす影響を考慮の上，施設毎の総合 的な健全性を $\mathrm{A} \sim \mathrm{D}$ の 4 段階に評価することとし ている（表-1）.

表-1 評価結果の分類 ${ }^{3)}$

\begin{tabular}{|c|l|}
\hline 評価 & \multicolumn{1}{|c|}{ 施設の状態 } \\
\hline$A$ & 施設の性能が低下している状態. \\
\hline B & 放置した場合に, 施設の性能が低下する恐れがある状態. \\
\hline C & $\begin{array}{l}\text { 施設の性能にかかわるる変状は認められないが, 継続して観 } \\
\text { 察する必要がある状態. }\end{array}$ \\
\hline D & 0 異常は認められず, 十分な性能を保持している状態. \\
\hline
\end{tabular}

\section{b) 維持管理計画書の体系の概要}

維持管理計画書は, 新設構造物では設計段階, 既 設構造物では初回点検診断実施後に作成されること となった。

維持管理計画書は, 小規模な施設を除き, 各々の 構成部材毎に維持管理レベルを設定（表-2）し，そ のレベルに合わせた維持管理の方針を定めることを 基本としている. その上で, 点検診断計画, 総合評 価, 維持補修計画などを策定することが「手引き」 に示された。これらにより, 維持管理計画書の作成 とこれに基づく維持管理の取り組みが実行段階に移 された.

「手引き」では，新設構造物の計画策定を念頭に 作成されており，「設計供用期間 50 年にわたり適切 に維持すること」を「計画の目標」として例示して いる. しかし，港湾施設の設計供用期間として一般 に用いられている 50 年は, 施設の設計に用いる外 力の再現期間の設定に関係するものであり, 施設の 供用期間と直接リンクしない場合もある.

表-2 部材の維持管理レベル 4)

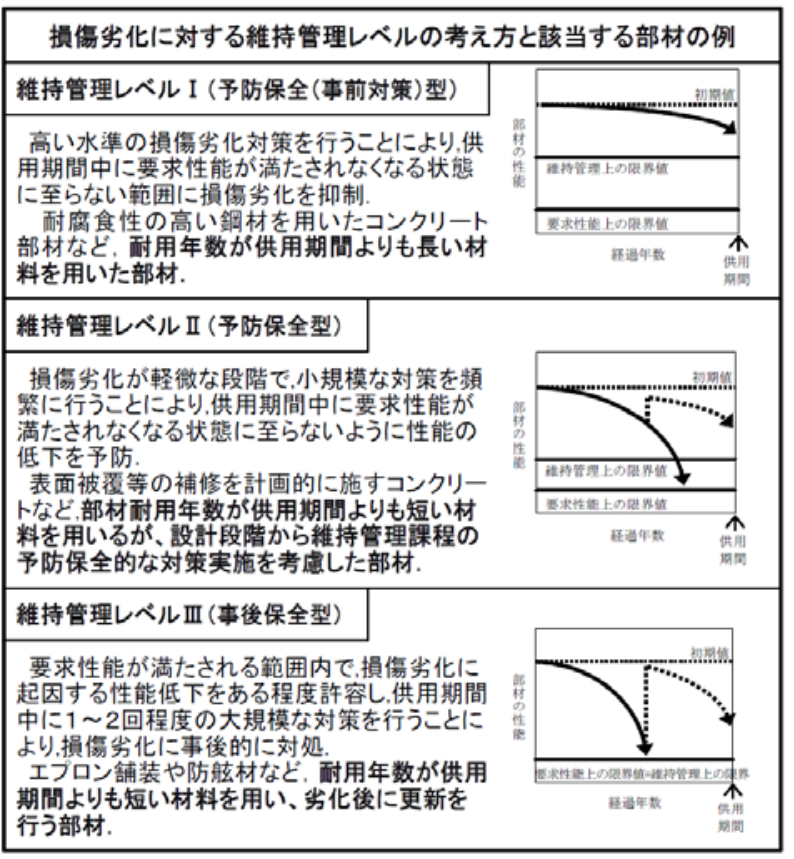




\section{c) 施設の変状進行予測等の体系の現状}

「マニュアル」においては, 多種多様な港湾施設 の特徵を踏まえ, 劣化予測は部位・部材毎に行うこ とが望ましいとした上で, 鋼構造物とコンクリート 構造物の劣化メカニズムや劣化予測手法を紹介して いる. 一方，同一構造物内での劣化進行のバラッキ があることなどから, 構造物全体の劣化予測の手法 として，確率論的モデルであるマルコフ連鎖モデル を紹介している.

しかし，「手引き」は，新設構造物の維持管理計 画作成を念頭にしており, 供用開始後の点検結果に 基づく維持管理方針のあり方の言及にまで至ってい ない。 また, 現在, 制度発足後の初回点検や計画書 作成がほぼ一巡した段階であり，行政的にも，供用 後の施設のアセットマネジメント手法の体系化にま で至っていない.

\section{d) アセットマネジメント手法に関する研究の現状}

港湾施設のアセットマネジメントの体系化に向け て, 高橋ら ${ }^{6)}$ は, 様々な規模の施設群を各々の空間 規模やその役割に応じてマネジメントすることが必 要であるとして, 港湾のアセットマネジメントのあ り方や, 施設の維持補修等の優先度検討のケースス タディを紹介している.

また, 加藤ら”は, 栈橋のライフサイクルマネジ メントシステムとして, 要素技術として蓄積した知 見を体系的にとりまとめるとともに，個々の要素技 術を結びつけた手法を提案し, 維持管理計画の策定 を支援するプログラム開発を行っている.

これらの取り組みは，それぞれ，個々の施設の利 用状況に関する様々な要因や，施設に関する詳細な データに基づくいわゆるミクロ分析である．埠頭や 港湾全体を見渡したアセットマネジメントとして, 補修工事の要否や実施時期を, 総合的に検討するた めの情報提供を行うためには, 詳細なデータの蓄積 や, 実務的に利用可能なデータベース構築を待つ必 要がある.

\section{2. 経済社会の変化によって利用ニーズが変動す る港湾の施設}

\section{(1) 社会基盤施設の中での港湾の特殊性}

他の社会基盤施設に比較して, 海象条件や地盤条 件など，㛜しい自然環境下に置かれることが，港湾 施設のマネジメントの特殊性として触れられること が多い。これらの詳述は他に譲り, 資産マネジメン トの観点からの特殊性について触れる. a) 私企業の経営判断が左右する利用施設の選択

他の社会基盤施設, 例えば一般道や上下水道では, 利用者が事業者（サービス提供者）を選択する余地 が少ない.

一方, 港湾の利用者の多くは, 船会社や荷役作業 等にあたる港湾関連企業, 臨海部に工場等を構える 製造業などの私企業である，利用者は，経済効率性 や事業継続性などを勘案した経営判断として, 物流 ネットワークを構成する要素の一つとして港湾や埠 頭の選択行動をとる. 寸なわち，港湾は，企業等の 利用者から見れば, 複数の選択肢からの選択対象と なる特殊な基盤施設である。

例えば，首都圈発で上海方面向けに貨物輸送する 航路利用者は, 東京湾内でコンテナ船が就航する東 京港や横浜港, 航空輸送による成田空港などの外に, 2003 年就航の国際 RORO 船が就航する博多港など, 複数の選択肢の中から輸送時間や輸送費用などを勘 案した経営判断で港湾を選択している.

b) 物流ネットワークのノードを構成する港湾

道路利用者は, 発着地間に張り巡らされる道路ネ ットワークから, リンクの組合せを選択して, 走行 する（図-2）。また，上水道利用者であれば，水源 - 浄水場から各家庭・事業所の地先までの一体的に 運営されるネットワークから, 給水サービスの提供 を受ける. 補修工事等に伴う通行止めや断水があっ ても，これを理由に，利用者がサービスの享受を中 止すること（提供事業者の選択変更）にまで至るこ とは無い。

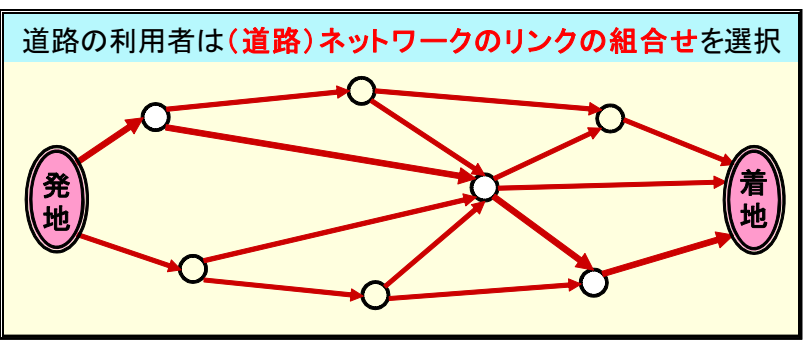

図-2 ノードから構成される社会基盤のイメージ

しかし，原料産地から工場，工場から消費地など をドアツードアで輸送する物流において, 港湾は, 物流ネットワークの中で選択対象となる一つのノー ドに過ぎない(図-3).

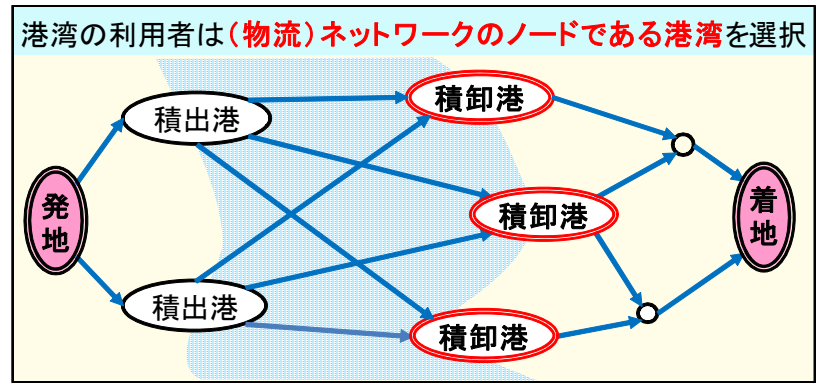

図-3 物流網の中で選択されるノードとしての港湾 
フォワーダー(荷主との運送契約を行い, 運送事 業を行う他者のサービスを利用し，運送を行う事業 者)から見れば，輸送に要する時間や料金等から選 択するノードの一つに過ぎず，定期航路を運行する 船会社から見れば，ターミナルの効率性や集荷力を 勘案して選ぶ寄港地の一つに過ぎない.このため, 補修工事によるサービス低下の期間や程度によって は，選択ノード（輸送ルート選択）の変更を招き， 利用者のサービス提供事業者 (利用港湾) の選択変 更も生じる。すなわち, 補修工事の実施方法の是非 によっては, 当該港湾の顧客を喪失する可能性を秘 める特殊な基盤施設である.

例えば, 日本の国際コンテナ貨物の約 3 割（約 2.7 百万 TEU：1994 年）を扱った神戸港が，阪神淡路 大震災による災害を一年半で復旧したにもかかわら ず，未だコンテナ取扱個数 2.1 百万 TEU を越えら れない（約 2.1 百万 TEU : 2011 年. 国内港計の約 12 \%) 現状が,一旦喪失した顧客の回復の難しさを示 している.

\section{c) 利用船舶の規格の自由度を利用者が握る港湾}

道路や軌道は，その幅員や橋梁・トンネルの建築 限界等によって, 通行可能な車両の限界が規定され る.すなおち, 一部の限られた特殊な車両を除けば, 車両側の自由度には限界があり, 社会基盤の限界值 に収まるような車両が走行する。

一方，港湾を利用する船舶，特に国際輸送を担う 外航船舶においては, 過去にはパナマ運河を通過可 能な船舶寸法が, 大型化の一つの目安とされていた. しかし，一部貨物を除き，寸法制限が無い外洋航行 が主流となり, 運航の効率性から進められる大型新 造船の建造, 航路体系の見直しによる寄港船の入れ 替え・大型化が進められた. 併せて, 複数港の施設 の整備状況や大型化の計画, 各港の取扱貨物量増減 の見通しなどを比較検討した上で, 寄港地変更も行 われた。 すなわち, 各々の港湾は, 道路等と異なり, 寄港船社や立地企業の意向によって, 規格の見直し （大型岸壁の整備など）をも余儀なくされる特殊な 基盤施設である.

代表的な例としては, 2001 年当時, 国内初の水 深 $16 \mathrm{~m}$ 級コンテナターミナルが供用したことによ り, 世界最大級のコンテナ船を建造中の船会社が, 主要ターミナルを置く港湾を変更した例がある。

\section{d) 技術革新や政策転換などで激変する利用施設の条 件}

港湾は，輸送の技術革新や内外各国の政策転換に よって, 直接的・間接的に利用状況の大きな変化を 被る場合のある特殊な基盤施設でもある。 その代表 的事例を 3 例紹介寸る.
(1) 輸送技術の進展によるニーズ変動

人力荷役が中心の時代には, 岸壁の直背後に倉 庫が配置されている櫛形の埠頭形状が理想とされ た.しかし, コンテナ輸送が主流の現在は, 背後 に広いヤード用地を備えた埠頭形状が理想となっ ている.

古くは神戸港の摩耶埠頭, 近年では横浜港の本 牧埠頭で, ニーズに合わせた埋立や岸壁増深によ り埠頭形状の変更を行っている.

(2) 輸出入国の政策転換によるニーズ変動

輸入木材を一時保管する港湾施設は, 南洋材の 原木輸入に相応しい水面貯木場から，輸出国の政 策転換により製材としての輸入や，輸入原木の北 洋材への転換により, 陸上ヤードへとニーズが変 化した。また， 2009 年に中古車輸入関税を急騰 させたロシアの政策転換により, 日本海側港湾か らロシア極東各港への中古車輸出が激減した.

(3) 国内政策の変化によるニーズ変動

高速道路で行われた 2009 年からの休日上限料 金制, 2010 年からの路線無償化等の長期間の社 会実験実施に伴い, 瀬戸内海などのフェリ一航路 では利用者が激減し, 航路の減便・廃止による各 港のフェリーターミナルの稼働率低下・遊休化が 相次いだ. 国内の政策の変化も, 港湾の利用に激 変をもたらす。

\section{（2）経済社会情勢によって変化する港湾の利用ニーズ} 前節に述べた港湾の特殊性について, 資産マネジ メントの観点からの寿命と捉えて整理する.

\section{a)「物理的寿命」と「経済·社会的寿命」}

本論文では, 土木施設として, 当初の設計で想定 した水準での強度や形状を保持し, 安全かつ安定的 に利用できる状態を維持している期間を，「物理的 寿命」と定義する.

一方，施設の建設・改良の計画時点に土木施設と して応えようとした経済・社会活動からの要請その ものが存続する期間, あるいは, 要請に応えるに十 分な規模・設備のサービス水準を提供し続け得る期 間を, 当該施設の「経済・社会的寿命」と定義する.

これら「物理的寿命」と「経済・社会的寿命」の 内，期間の短い方が当該施設の「寿命」となる.

\section{b) 経済·社会的寿命変化への配慮の必要性が低い他 の基盤}

主要幹線道路, 例えば, 都府県境を跨る幹線道路 の橋梁や, 都市内高速道路などは, 道路交通網の充 実による交通量や大型車混入率の変化などがあって も, 存在自体が不要になることは無い.

このため, 安全で快適な走行が可能な状態を, 経 
済的・効果的に確保しておく物理的寿命の延命化 が, 維持管理上の最大の命題になる. 仮に, 補修工 事や更新（架け替え）を実施する際にサービス水準 の低下などが長期化しても, 終了後には利用者は回 帰し，利用者（顧客）喪失までを招くことはない。

\section{c) 経済·社会的寿命変化に施設寿命が左右されやす い港湾施設}

港湾施設においても, 他の社会基盤施設と同様に, 物理的寿命の把握や延命化等のための措置は重要で ある.しかし，前節に述べたとおり，計画・建設段 階では想定できないような経済・社会情勢の変化を 受け, 施設の存続意義が左右されることが生じる.

港湾施設は, 安全かつ安定的に利用できる水準を 維持し続ける構造面からの物理的寿命と, 施設の存 続意義を左右する経済・社会的寿命とが共に継続す ることにより，当該施設の寿命が決まる.

\section{（3）利用ニーズの変動への対応が不可避な港湾施設}

港湾施設の寿命が, 物理的寿命と経済・社会的寿 命のいずれで決まるかは，一概に言えない，それぞ れの寿命が顕著となる例を紹介した上で，供用後の 維持管理過程において, 利用ニーズ変動への対応の 必要性を述べる.

\section{a) 物理的寿命と経済·社会的寿命の関係}

(1) 物理的寿命により施設の寿命が決まる例 素材型産業を始めとして, 大規模な設備投資を 行った上で操業する事業所で，原材料搬入や製品 出荷で港湾施設が不可欠な場合, 企業統合に伴う 事業所廃止などが無い限り, 生産工程に欠かせな い一施設として, 港湾施設の利用は継続される.

こうした場合, 半永久的な経済・社会的寿命が求 められるため, 物理的寿命の延命化が, 施設の寿 命を大きく左右させることとなる．

(2) 経済・社会的寿命により施設の寿命が決まる例 経済社会のグローバル化等による企業の経営判 断や内外各国の政策転換による影響を受けやすい 岸壁などの寿命は, 定期航路の寄港中止や主要貨 物の取扱量の激変などにより決定づけられる。こ れらは，施設建設の計画段階では見通すことの出 来ない要因であり, 経済・社会的寿命の激変が, 物理的寿命の残期間の長短に関わらず，施設の寿 命を大きく変化させる.

国内では，一部のターミナルを除き，岸壁や貨 物上屋は, 国や港湾管理者などの行政が, 荷役施 設や保管施設は, 港湾運送事業者や倉庫業者が, それぞれ所有・運営している。このため, 船会社 や荷主，フォワーダーなどの利用者は，港湾等の 選択に関して資産管理上のしがらみが少なく，自
社の経営資源に焦点を当てて寄港地や輸送ルート の見直し判断を行うことができる.

(3) いずれの寿命により決まるか見通せない例 施設計画時点の利用ニーズが途絶えても, 物理 的寿命を残している場合には，第二の利用ニーズ の開拓や，他施設利用者のシフトなどにより，引 き続き施設の利活用が継続される例もある。

・ コンテナ船の大型化で利用頻度が低下したコ ンテナターミナルの一部を, 完成自動車の輸出 ターミナルとして活用 ( $\mathrm{YK}$ 港, 写真-1).

・原木輸入の伸び悩む岸壁 2 バースの内の一つ を, 近傍の工場の出荷岸壁として活用 (KS 港).

・ 工場再編で利用が激減した大水深バースを, 新規誘致した飼料サイロの原料輸入用岸壁とし て再編・活用 (KM 港).

- 在来船の利用埠頭の利用再編を行い, 東アジ ア域内航路のコンテナターミナルとして活用 (NG 港).

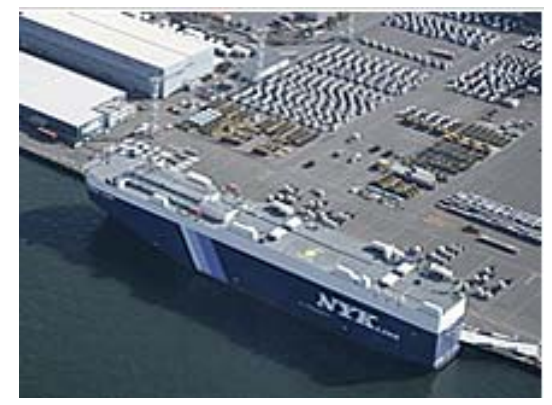

写真-1 自動車輸出に活用される旧コンテナターミナル 8)

こうした第二，第三の利用需要による経済・社会 的寿命の延長は, 港湾管理者や港湾運送事業者など による地域に密着した主体が行う地域や港湾の振 興, 既存施設の活用等の観点からの取り組みが結実 した際に叶うものである. 施設の計画段階や, 計画 段階の利用需要に対応した経済・社会的寿命の末期 の時点で, 予め見通すことは困難である. 現実的に は多くの施設が，いずれの寿命が当該施設の寿命を 決定するかを予め見通すことは容易でない.

b) 経済・社会的寿命を睨んだ維持管理が必要な港湾 施設の計画時点から当該施設の経済・社会的寿命 が見通せる場合は，これを以て供用予定期間として 建設することができる。しかし，経済・社会的寿命 は，グローバルな経済社会情勢の変化や，これに対 応するための製造業や運輸業の経営戦略に大きく左 右されるものであり, 計画時点で高い精度で寿命を 見通すことは実務上困難である。

近年では, 国際的な資源確保競争々輸送効率化の ために進んだ更なる貨物船の大型化（図-4）, リー マンショックや欧州経済危機に伴う経済低迷の中で の船腹過剩，円高に伴う日本企業の国際的生産体制 
の見直しが生じて起こっている．また将来において も，人口減に伴う国内消費財の物流縮小，米国東岸 航路のボトルネックになっていたパナマ運河拡張完 成（2014 年予定）による貨物船サイズの再編など, 見通しの立てがたい不確定な要素が海運を巡ってい る状態にあり，経済・社会的寿命は大きく左右され る.

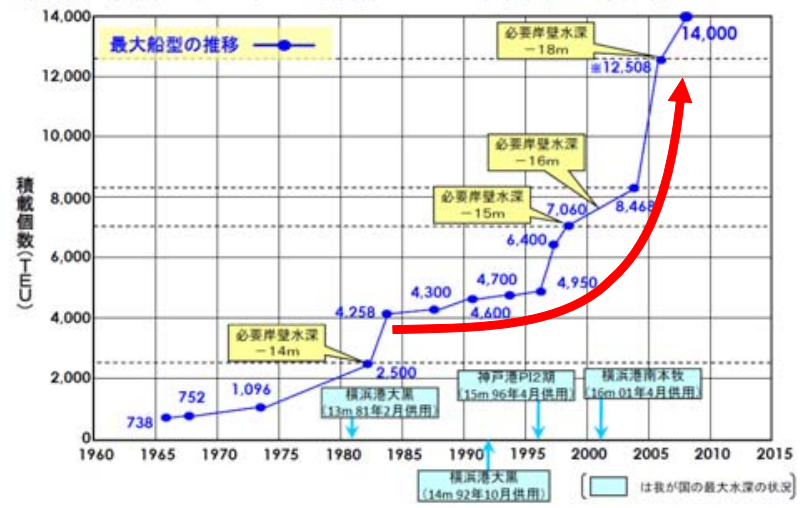

図-4 急激に大型化が進む国際コンテナ船 （国土交通省交通政策審議会資料(2010)を基に作成）

このように, 長期間に亘り貨物船が利用する個々 の岸壁を取り巻く数十年先までの経済・社会情勢を 高い精度で予め見通寸ことは，困難である。

港湾施設のアセットマネジメントを効果的に進め ていくためには, 経済・社会的寿命の変動にも柔軟 に対応できるマネジメント手法が不可欠となる.

\section{3. 利用ニーズ変動対応型のアセットマネジメント手法}

(1) ニーズ変動を見通した補修計画立案方法の必要性

多くの港湾施設の維持管理計画書は, 本論文でい う物理的寿命が設計供用期間の 50 年を下回らない ように管理することを目標として作成されている. しかし, 港湾施設の寿命は, 利用ニーズに基づき決 まる経済・社会的寿命に左右され，物理的寿命だけ では定まらないのが現実である。半永久的な経済・ 社会的寿命が見込まれる場合は, 設計供用年数 50 年を越える長期的な見通しの中で維持管理方針を考 えるべきである，一方，設計供用期間の 50 年を迎 える前に, 経済・社会的寿命を迎える事態になる場 合には, 物理的寿命が 50 年を超過しないように維 持管理を進めることが合理的となる.

1-(2)で述べたように, 港湾施設のアセットマネ ジメントシステム体系は, 供用開始後の手法の提示 までには至っていない。このため, 施設の供用期間 中の一定のタイミングで, 逐次, 経済・社会的寿命 の長期化・短期化を評価し, 物理的寿命の延長対策 の要否を定めることが合理的である.
(2) ニーズ変動を見通した補修計画立案手法の提案

\section{a) 提案手法について}

本論文では，経済社会変化による利用ニーズ変動 に対応可能な港湾アセットマネジメント手法を提案 する(図-5).

本手法は，施設の点検結果に基づき，構造物の劣 化進行を連続的に表現できる指標により，健全度低 下の進行を評価し，予防保全や事後保全のための措 置実施の是非判断のタイミング前に, 物理的寿命を 見通すこととする。その際, 併せて, 経済・社会的 寿命の見通しを把握することで，その都度，経済社 会情勢の変化による利用ニーズ変動に併せた維持管 理方針の見直しを行うものである.

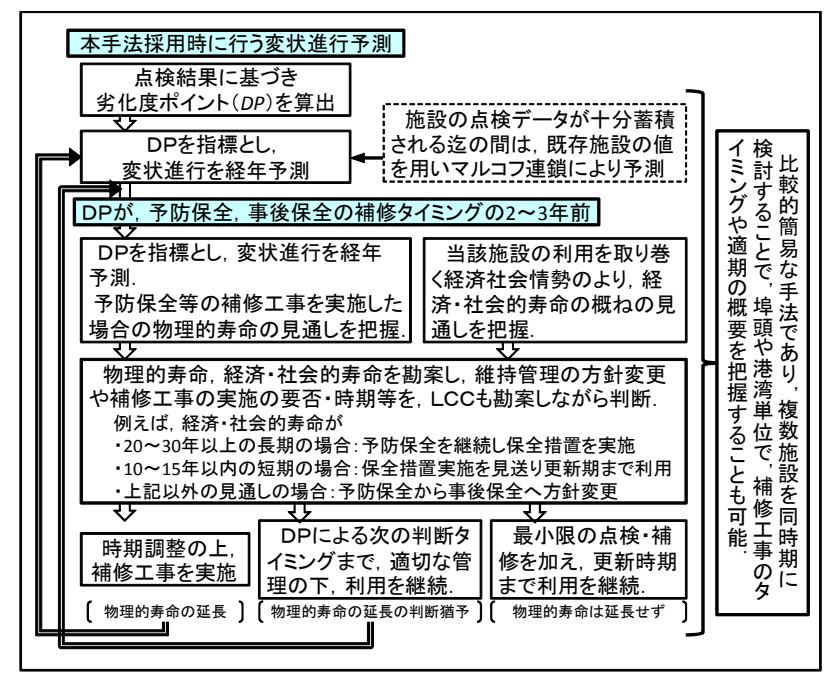

図-5 利用ニーズ変動対応型のアセットマネジメント手法

\section{b) 提案手法の特徵}

これまで，当該施設を取り巻く将来の経済社会情 勢予測は, 施設の計画時点と建設時点の限られた夕 イミングで行っていた。. また, 当該施設の構造物の 健全度評価は, 経済社会情勢の見通しとは別に実施 し, 当該施設に求められる残供用年数（本論文でい う経済・社会的寿命の残存期間に相当）との関係性 を十分考慮しないままに, 設計供用期間の 50 年目 を目処に行われることが一般的であった.

本手法は，これら個別に行われていた寿命の見込 みを総合的に検討するものである．施設供用期間中 に, 予防保全措置の時期や事後保全としての補修時 期などに, 改めて, 当該施設が期待される経済・社 会的寿命の見通しを把握することで, 利用ニーズに 対応した維持管理方針の変更の是非判断を可能にす る.

また，供用開始後 50 年目の経済社会情勢の見通 しも，供用開始後 $20 \sim 30$ 年目前後の予防保全措置 実施判断の時期，供用後 $30 \sim 40$ 年目前後の事後保 全措置実施判断の時期などに行うため, 当該施設の 
計画時よりも精度が高く，実態に即した見通しを得 ることができる.

劣化進行による物理的寿命の予測は, 予測精度の バラツキは大きいものの，簡易に予測できるため， 複数施設を同時期に検討寸る際の行政事務負担も少 なくすることができる，このため，埠頭単位あるは 港湾単位などに適用寸ることで, 補修工事のタイミ ングの把握や実施スケジュールの立案, 維持管理方 針の適切な組合せ検討など，供用開始後の施設群と してのマネジメント検討にも実用的なものである.

\section{c) 提案手法の実施に用いる条件等}

(1) 施設の連続的健全度指標々補修等要否判断値 施設の劣化進行状態を連続的かつ総合的に示寸 指標と補修工事のタイミングに相当する判断指標 值は，著者ら ${ }^{9)}$ の報告で提案し，式(1)で定義さ れる指標である「劣化度ポイント $D P 」 を$ 用いる。

$$
D P=W_{1} a+W_{2} b+W_{3} c+W_{4} d
$$

ここで, DP : 劣化度ポイント, $W_{1} \sim W_{4}$ : 各 劣化度に対する重み係数 $\left(W_{1}=4, W_{2}=3, W_{3}=2\right.$,

$\left.W_{4}=1\right), a \sim d:$ 劣化度 $\mathrm{a} \sim \mathrm{d}$ がそれぞれ占め る割合.

また，補修工事のタイミングに相当すると判断 する DP の值として予防保全では 2.5, 事後保全 では 3.15, 更新では 3.8 の值を用いる.

なお，この重み係数や判断する指標值としての DP 值については, 過去の補修時期設定の経験上 設定した值であり, 引き続き研究が進められてい る值であることに留意が必要である.

(2) 劣化予測手法としてのマルコフ連鎖モデル ${ }^{4)}$

港湾施設は, 同一構造物内での劣化進行のバラ ツキがあること等から，構造物全体の劣化予測を 行う方法として, 確率モデルによって変状の進行 を再現するマルコフ連鎖モデルを用いる．

マルコフ連鎖モデルは,「状態」と「推移」と いう2つの概念を用いて, 物事がある状態から, ある「遷移率 $P_{x}$ 」で次の「状態」へと移行する 様子を確率論的に捉える統計手法である. 初期状 態では, 全ての部材の劣化度が $\mathrm{d}$ であるとする. また, 遷移率は劣化速度を表す指標であり, 本研 究での計算を行う際は一定值として扱う.

なお，計算に用いる遷移率は，古谷ら ${ }^{10)}$ が, 全国の国有港湾施設の係留施設 335 施設を対象と して構造形式毎に分析した結果を利用する.

(3) 維持管理の対応方針

本論文では, 物理的寿命（劣化）への維持管理 の対応方針は, 以下の 3 ケースとする.

イ）予防保全：建設時における劣化予防策の実
施およびその対策の更新

口）事後保全：発生した劣化箇所の除去・復旧 による事後保全

八）更新 : 利用継続のための施設の撤去・再整 備

\section{d）試算結果とニーズ変化の見通しに応じた補修実施 の判断例}

以上の条件の下で, 栈橋の補修工事の実施タイミ ングを予測し，その時点での補修工事の実施有無に より変化する DP の様子を図-6に示す.

図-6の実線は，施設建設後 28 年目に，予防保全 を行う $\mathrm{DP}=2.5$ に達する。 ここで, 補修等の対策を 講じない場合 (以下, 「未措置」という), 36 年目 に事後保全の措置を行うタイミング $\mathrm{DP}=3.15$ を, さらに, ここでも未措置の場合, 54 年目に更新工 事を実施するタイミング $\mathrm{DP}=3.8$ に達すること示し ている.

なお，試算においては，古谷ら ${ }^{10)}$ の分析事例か ら, 栈橋の確率密度関数の累積度数 $75 \%$ に相当す る遷移率 0.116 を用いる. また, 試算例においては, 建設段階において予防保全措置としてコンクリート の表面被覆が施されているものとし, 効果持続期間 中においては, この遷移率の $1 / 2$ である 0.058 とし $た^{11)}$.

以下，建設後 25 年目に施設の点検を実施した場 合に, 利用ニーズが存続する期間を睨みつつ, 補修 対策の実施の是非を判断する複数回のタイミングを 活かしながら行うアセットマネジメントの例を紹介 する.

(1) 最初 (28 年目)に迎える予防保全時期の判断

例えば, 将来に亘る操業継続を前提とする企業 が所有する岸壁のように, 半永久的な供用が必要 な岸壁（物理的寿命により寿命が決定する）であ り，予防保全措置を繰り返すことが適当と判断す れば， DP=2.5 に達する都度（遷移率が同一であ れば 28 年毎）に予防保全策を繰り返すことで, 計算上は半永久的な供用継続が可能となる（図中 の一点鎖線).この判断を下した場合は, 3 年後 の 28 年目の補修工事実施に向けた財政措置や補 修工事期間中の利用調整の準備を開始する.

(2) 36 年目に迎える事後保全時期の判断

(1)の段階で，施設の利用状況などから半永久的 利用の必要性が無いと判断すれば，予防保全の措 置は見送られ，36 年目に次の補修等実施判断時 期を迎える（1)で 28 年目の予防保全措置を見送 った場合においては，28 年目以降の試算におけ る遷移率は 0.116 としている).

$\mathrm{DP}=3.15$ となる 36 年目の事後保全措置を見送 
つても， DP=3.8 の更新タイミングを迎えるのは 設計供用年数以降の 54 年目であり, 計画上はま だ 20 年程度の利用が可能である。このため, 船 舶の大型化に伴う岸壁増深等の大型化改良工事, ヤードや工場の用地拡大の必要性からの施設廃止 や前面埋立などが，港湾計画の変更などで近い将 来に見込まれる場合は, 事後保全の措置を見送り， 定期的点検を繰り返しながら利用を継続する選択 を採り得る。

一方, 当初の設計供用年数を越えて利用ニーズ が続くと見込まれる場合には，事後保全措置を講 ずることによって DP $\leqq 3.15$ の状態を 58 年目ま で延長（図中の破線．更新期となる $\mathrm{DP}=3.8$ は 76 年目）させる選択を採り得る（計算上は 58 年目 以降も事後保全策を講ずることで 22 年ずつの延 命化が可能)。この際，LCC 比較や利用状況を始 めとした経済社会的状況を勘案すれば，54 年目 に施設の更新を行い 100 年目以降迄の供用期間を 確保寸る選択肢（図中の点線）も検討の対象とな り得る.

(3) 56 年目の 2 回目の予防保全時期の判断

(1)の 28 年目に予防保全措置を行った場合, 56 年目に再度 $\mathrm{DP}=2.5$ となり, 予防保全措置の時期 を迎える。

この時点に於いても，(1)，(2)と同様に，半永久 的な供用継続のための予防保全の再措置を行うほ か， 56 年目は未措置とした上で， DP=3.15 とな る 64 年目での事後保全措置の実施の選択, $\mathrm{DP}=3.8$ となる 82 年目での廃止または更新など,
後年度に判断を見送る選択も取り得る（図中の二 点鎖線).

上記の試算例では, 施設建設後 28 年経過以降は, $10 \sim 20$ 年程度毎のタイミングで, 経済社会の変化 を背景とした利用ニーズを見通しつつ，延命化措置 の実施の要否や手段を判断する機会が訪れることを 示した.

本論文の考え方では，今回設定した值より大きな 遷移率であれば，判断タイミングは上記試算例より も短い間隔で訪れる。一方, 遷移率が小さい場合は, 更新のタイミングとなる $\mathrm{DP}=3.8$ に達する時期, す なわち, 物理的寿命を迎える時期が, 設計供用年数 に比べて, さらに長くなり, ニーズ変動対応型のア セットマネジメント手法を設計供用期間中に行うこ との実行性がそしくなる.

因みに，港湾行政においては，港湾法に基づく港 湾計画に基づき, 港湾の開発や利用が行われている. この港湾計画は, 当該港湾を取り巻く経済社会状況 の急激な変化に対応して行われる一部変更のほか に，概㪄 $10 \sim 15$ 年毎に定期的な全面的な見直しを 行い, 計画の改訂が行われている.

港湾計画の改訂作業と併行して, 利用ニーズ変動 対応型のアセットマネジメント手法による資産評価 を行うことで, 補修の判断のタイミングの間隔と同 等以下の短い間隔で, 定期的に補修の要否やその時 期等の検討も定期的に行える. また，このことで, 港湾計画についても, 改訂後 $10 \sim 15$ 年間に補修や 更新を想定するか否かの方針を持った上での計画内 容の検討・改訂を行うことができる.

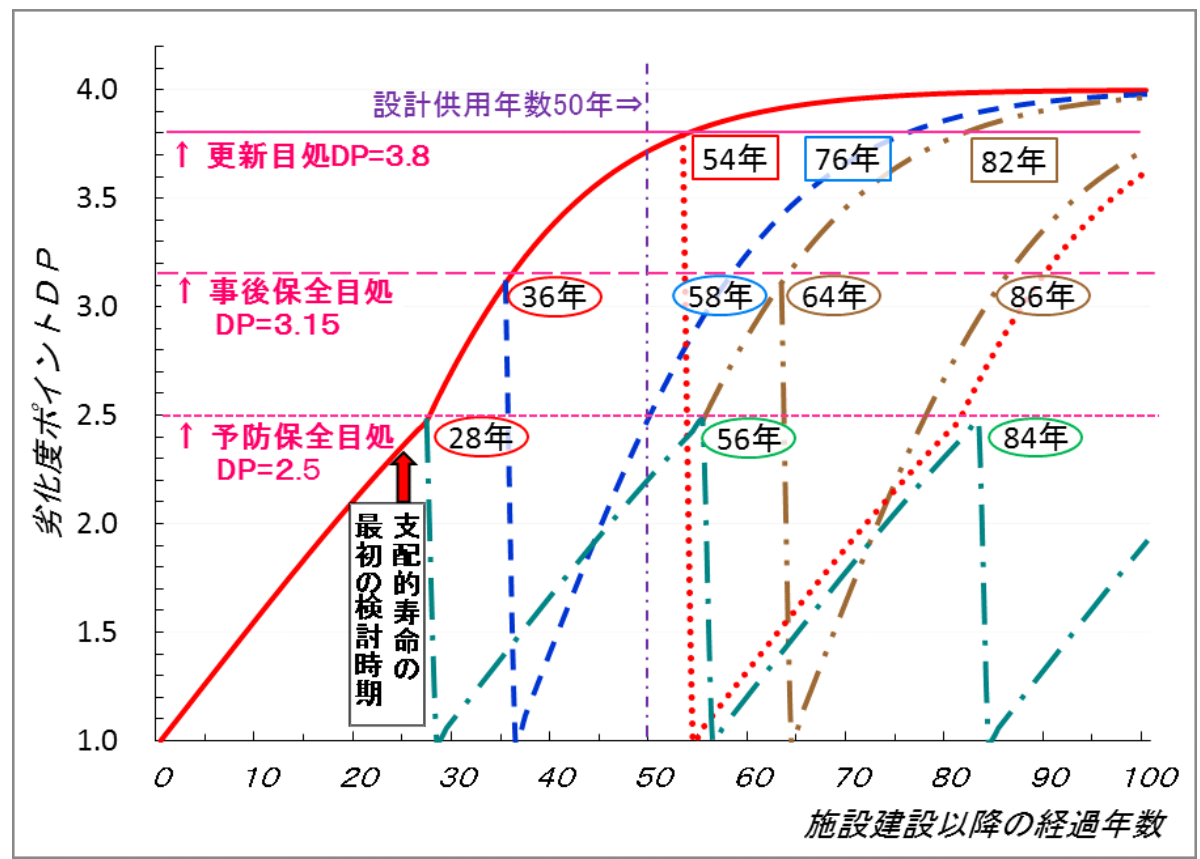

図-6 劣化度ポイント経年変化 [予防保全(事前対策)型] （予防保全期間 $\mathrm{P} x=0.058$, 保全期間終了後 $\mathrm{P} x=0.116$ ) 
(3) 今後の展望と課題

\section{a) 空間軸の観点からのアセットマネジメントプロセス構 築への展開}

港湾施設は，隣接する複数の岸壁であっても，そ の水深などの規模や，背後のサイロ等の保管施設の 配置などが異なり，隣接施設による代替性は容易に は確保できない。このため, 補修工事実施の優先度 順位の検討においても，各々の岸壁の補修順位を， 補修費用の一側面から検討することのみでは不十分 であり，施設群として捉えた検討が必要となる.

利用ニーズ変動対応型のアセットマネジメント手 法は，現状の劣化状態と遷移率などのデータより， 多数の施設に対して，複数の補修のタイミングを簡 易に予測することができる.

このため，港湾計画の改訂においては，各施設の 補修の要否やタイミングを施設群として捉え，補修 の順序や時期を検討する手法として活用することも 可能となる.

\section{b) 提案方法の実用性向上のための課題}

港湾施設の維持管理に関しては，2007 年の制度 改正を以て本格化したため, 施設点検もようやく二 巡目を迎えようとしている段階である。また，国有 港湾施設の設置者と管理者が異なる港湾特有の体制 もあり, 取得データの体系的な保管・分析に至って いない.

港湾施設の劣化状態に関する継続的かつ体系的な データ取得とデータベース化，ならびにこれらに基 づく分析・研究の進展は, 利用ニーズ変動対応型の アセットマネジメント手法も含めたマネジメントシ ステムの技術向上のために重要である.

\section{4. おわりに}

社会基盤施設の維持管理あるいはアセットマネジ メントの重要性については, 施設の設置者や管理者, 関係する研究者のみならず，政治的・行政的な話題 としても取りあげられる機会が増えている.しかし， 構造物の安全性評価や長寿命化など, 物理的な検討 が進む一方，当該施設の利用者との関係から捉えた 検討は，必ずしも十分には行われていない.

本論文では，経済的社会基盤である港湾を対象と して, 経済社会活動の中で避けられない利用ニーズ の変動との関係や，その利用ニーズ変動対応型のア セットマネジメント手法を提案した。構造面からの
物理的寿命のみならず，経済・社会的寿命にも配慮 した資産のマネジメントの体系構築の確立と，行政 における利用ニーズ変動に対応したアセットマネジ メント実施の契機となれば幸いである。また，LCC 計算による経済性の比較分析や, 遷移率のバラツキ に代表される物理的寿命の変動リスクの分析などと 組み合わせた体系の構築を進めることにより, 経済 的合理性も備えたアセットマネジメントのシステム 構築へ展開していくことを期待する.

\section{参考文献}

1）片岡眞二ほか：港湾構造物の改良・更新における技術 課題の検討，港湾技研資料，No.781， 1994.

2）交通政策審議会港湾分科会 安全・維持管理部会: 安全 で経済的な港湾施設の整備・維持管理システムのあり方に ついて，国土交通省港湾局，2005.

3）国土交通省：技術基準対象施設の維持に関し必要な事 項を定める告示， 2007.

4）(独) 港湾空港技術研究所 : 港湾の施設の維持管理技術 マニュアル，（財)沿岸技術研究センター，2007.

5）国土技術政策総合研究所 - (独) 港湾空港技術研究所 （財）港湾空港建設技術サービスセンター：港湾の施設の 維持管理計画書作成の手引き(増補改訂版)，（財) 港湾 空港建設技術サービスセンター， 2008.

6）高橋宏直・横田弘・岩波光保：港湾施設のアセットマネ ジメントに関する研究，国土技術政策総合研究所報告, No.29, 2006.

7）加藤絵万・岩波光保・横田弘：栈橋のライフサイクルマ ネジメントシステムの構築に関する研究, 港湾空港技術研 究所報告, Vol.48, No.2, pp.3-35, 2009.

8） (財) 横浜港埠頭公社 HP : 施設概要一大黒尔頭

9）佐藤瓦・横田弘・橋本勝文・古谷宏一・加藤博敏：、 ルコフモデルにより劣化予測を行った係留施設のライフサ イクルコスト分析, 土木学会論文集 F4 (建設マネジメント), Vol.67, No.4, pp.I181-I190, 2011.

10）古谷宏一・横田弘・橋本勝文・花田祥一：マルコフ 連鎖モデルを用いた係留施設の劣化進行予測の信頼性 評価，土木学会論文集 F4（建設マネジメント），Vol.67， No.4, pp.I159-I168, 2011.

11）山路徹・小牟禮建一・濱田秀則：塩害環境下に 15 年 間暴露されたコンクリートの耐久性及び表面被覆材による 塩害防止効果, 港湾空港技術研究所報告, Vol.44, No.2, pp.73-109, 2004.

(2012.5.14 受付) 


\title{
ASSET MANAGEMENT METHODOLOGY OF PORT FACILITIES TO MEET SOCIOECONOMIC CHANGES
}

\author{
Hirotoshi KATO, Shinichiro KITAZATO, Takeshi HYODO, Hiroshi YOKOTA
}

It is very easy to understand the importance of port facilities because they are expected to protect the hinterland and create social and economical bases. A port facility has a long lifetime and must be expected to meet demands during its lifetime that cannot be foreseen. However, it is rather difficult to forecast socioeconomic changes during such the long lifetime at the planning and design stages or even at maintenance stages.

For existing port facilities in Japan, because of the revision of the ministerial ordinances in 2007, it was obligatorily implemented to formulate a strategic maintenance plan and carry out performance/function-keeping work based on the maintenance plan. Under considering particularity of port structures mentioned above, it is very important to determine the period of service because the role of port depends on international relocation of production bases, choice of port call, and subsequent changes in needs and functions.

To realize excellent management of port facilities from the viewpoints of not only physical deterioration but functional obsolescence, the authors propose a facility management system taken into account the physical lifetime predicted by using the overall condition index and the socioeconomic lifetime to meet the changes in needs.

In this paper, current maintenance system and recent technological development for assessment on structural performance of port facilities are briefly summarized and some examples are introduced how the changes in needs have accelerated the obsolescence of port facilities. Then, the facility management system proposed is discussed with providing its application examples. 